"There would be no need to write a letter about this if it were not for the inflammatory statements made by Jonathan Mann which aren't based on science," says signatory Robert Doms, University of Pennsylvania. Ralph Steinman from Rockefeller believes that "Mann has greatly distracted from the very real effort going on to intensify vaccine research."

In an interview with Nature Medicine, Mann claimed to be pleased that the debate is out in the open, but insisted that the remarks attributed to him have been taken out of context. He said that the letter gave a "biased interpretation" of his testimony to PACHA and maintains that he is not calling for NIH removal from the project, merely its supervision by another body that would be prepared to push ahead with empirical trials.

Mann was also reported to have labeled David Baltimore, who heads a commission on HIV vaccine development, and NIH director Harold Varmus as 'incompetent,' but strongly denied such a slur on two scientists for whom he has "great respect." Needless to say, the letter was a demonstration that many of the country's top AIDS researchers are fully behind the two. Those questioned heaped praise on the Bal- timore Commission for its funding of innovative research, the quality of its members and the fact that it travels around the country seeking opinions on vaccine development. "They're asking hard questions and are being very inclusive," said one researcher.

Like Mann, PACHA argues for empirical testing of vaccine candidates, such as the gp120 subunit vaccine, on the grounds that this approach has yielded successful vaccines in the past. Meanwhile, the scientists are adamant that there is no vaccine currently available that is worthy of testing.

"The gp120 subunit vaccine strategy was developed years ago," sighs Doms. "In the meantime, our understanding of HIV biology and antigenic structure has increased tremendously and in my opinion the gp120 vaccines are a complete waste of time, effort and resources." Doms illustrates what he and others regard as the futility of testing the vaccine with the more recent knowledge of the role of chemokine receptors: "Subunit vaccines are directed against T-tropic viruses that use the CXCR4 co-receptor and are not even the viruses that are transmitted from person to person."

Surprisingly, activist Derek Link of Gay Men's Health Crisis, whose boss Ronald
Johnson is a PACHA member, also signed the letter. "Although we want a vaccine as fast as possible, wishing it so doesn't make it so," says Link who prefers to trust the judgement of the country's best scientists as to whether there is a suitable candidate for large scale testing. He adds a concern that is common to the group of signatories: "There isn't an infinite number of HIV-infected people available, they are a valuable resource and it would create a lot of ill-will if a test goes wrong."

Link also raises an interesting caveat: "Right now most activists and HIV/AIDS patients are not plugged in to vaccines. In fact, a Kaiser Permanente questionnaire of [an ethnic group of patients] showed that 13 percent and rising believe that there is already a vaccine available to prevent AIDS." But that situation is changing. May 18th was the first HIV/AIDS Vaccine Awareness Day in recognition of the 2,750 US volunteers who have so far participated in preventive vaccine trials. As the AIDS community's understanding and interest in vaccine development grows, the opinions of both PACHA and the researchers may be drowned out by a force renowned for its ability to get things moving in this arena. Karen Birmingham, NeW York

\title{
Bill paves the way for more birth defects research
}

A bill signed into law by President Clinton on April 21st authorizes a substantial increase in federal funding for research into birth defects and opens the door for new initiatives in the future.

Representative Solomon Ortiz (DTexas) has been pushing for passage of the bill since 1992, after a cluster of birth defects occurred in his district. While the cause of that outbreak still has not been determined, the measure has served to educate legislators about this category of conditions-the leading cause of infant mortality in the United States.

The new legislation calls for a budgetary increase this year to $\$ 30$ million from the $\$ 26$ million that Centers for Disease Control and Prevention (CDC) currently receives through appropriations bills that were passed as an interim measure, and for $\$ 40$ million next year. Getting that money to scientists though, will require an additional act of Congress. "This is really an authorization bill, so there's no money here [yet]. It authorizes the program. Funding comes through a different source," explains Joanne Merrill, a spokesperson for the March of Dimes, a nonprofit organization which lobbied strongly for the bill's passage. The practical effect of the bill is to define the goals of the program, establish its political legitimacy and help secure future funding.

The new bill endorses coordinated, federally-funded research into the biology and epidemiology of birth defects and also calls for efforts in education and prevention to be stepped-up. The program will be managed by the CDC and will focus initially on eight regional centers scattered across the country, including one based at the CDC, which are already set up to study birth defects.

A group of scientists is being assembled under the title of National Birth Defects Prevention Network, to share information and standardize the methods used in studies of birth defects. "In this country, there's been no central funding mechanism to help set up studies of birth defects. Sometimes there are 50 different opinions of how that ought to be done," with each state pursuing its own approach says Larry Edmonds, Associate Chief of State Services in the Birth

\section{IMAGE UNAVAILABLE FOR COPYRIGHT REASONS}

Defects and Developmental Disabilities Branch of the CDC

Researchers have hailed the measure as a much-needed boost for work in a neglected area of medicine. "I think it's long overdue. There's an incredible need for further research and understanding as to the mechanisms involved [in birth defects]," said Mike Artman, director of pediatric cardiology at the New York University Medical Center. Like others in the field, Artman hopes that the new legislation will pave the way for similar projects at other agencies: "This hopefully will turn the spotlight on and get people's attention so that we can move forward." Alan Dove, New York 